\title{
Strategi Rebrand Usaha Berbasis Rumah Tangga Melalui Desain Ulang Tempat Usaha di Kecamatan Pandaan, Kabupaten Pasuruan
}

\author{
Andarita Rolalisasi \\ Universitas 17 Agustus 1945 Surabaya \\ Khoudiy Iffiyah \\ Universitas 17 Agustus 1945 Surabaya
}

\author{
Intan Kusumaningayu \\ Universitas 17 Agustus 1945 Surabaya
}

Shinta Fiqi Hutama

Universitas 17 Agustus 1945 Surabaya

\begin{abstract}
This paper presents the community service (PKM) implementation for home-based enterprises Pia "Mahen". The purpose is to re-design working place as a producing place and as a training center of Pia making through provided a layout design. These two functions took the same place currently. This condition interferes with each function. This PKM is involving students to apply their design knowledge. The implementation method is used technical assistance for re-design of the working place and the training center. Through the redesign of working place, Pia "Mahen" is expected to be increasingly widely known as a producing place of pia and a training center of pia making.
\end{abstract}

Keywords: Home-based enterprise, Re-design; Rebrand; Working place

\section{Abstrak}

Paper ini menyajikan hasil pelaksanaan Pengabdian Kepada Masyarakat (PKM) di Usaha Berbasis Rumah Tangga (UBR) makanan Pia Mahen. Tujuannya adalah mendesain ulang tempat usaha sebagai workshop produksi dan pelatihan melalui desain layout secara dua dan tiga dimensi untuk mempermudah pelaksanaan renovasi oleh pengusaha. Selama ini, kedua fungsi tersebut terletak pada tempat yang sama sehingga saling mengganggu. PKM ini melibatkan mahasiswa sebagai sarana belajar untuk mengaplikasikan ilmu desain yang diperoleh selama kuliah. Metode pelaksanaan PKM ini adalah mendampingi proses desain ulang tempat usaha melalui penyediaan gambar desain sesuai keinginan pemilik usaha dan pengembangan usaha di masa depan. Melalui desain ulang tempat usaha, Pia Mahen diharapkan akan semakin dikenal secara luas tidak hanya sebagai pusat produksi makanan semata namun juga sebagai tempat belajar pembuatan makanan pia.

Kata kunci: Desain ulang; Tempat usaha; Ubah citra; Usaha berbasis rumah tangga

\section{Pendahuluan}

Salah satu program pemerataan pembangunan yang sesuai dengan kondisi demografi Indonesia adalah pembangunan jalan tol Trans Jawa dari Anyer sampai dengan Banyuwangi. Fungsi utama pembangunan tersebut adalah untuk mempercepat pertumbuhan ekonomi dan meningkatkan pelayananan publik. Pembangunan jalan tol Trans Jawa melewati empat provinsi dan memiliki lima belas ruas tol. Keberadaan jalan tol bisa berpengaruh terhadap kondisi fisik, sosial, dan ekonomi (Sumaryoto, 2018). Menurut Mukhlis dan Soetomo (2017), terdapat simpulsimpul kegiatan baru (newly growing) di sekitar kawasan exit tol, namun sebaliknya juga ada penurunan (decline) aktivitas perdagangan akibat pengguna koridor regional yang beralih ke jalur tol. 
Pia Mahen bukan sekedar showroom penjualan Usaha Berbasis Rumah Tangga (UBR) namun juga sebuah tempat untuk pelatihan membuat pia secara gratis. Bu Srinah (pemilik usaha) membuka pelatihan dengan jadwal yang telah disepakati kepada siswa-siswi taman kanak-kanak sampai dengan sekolah menengah pertama. Hal ini untuk meperkenalkan pia dan memupuk kewirausahaan sejak dini. Peserta pelatihan tidak hanya dari Kabupaten Pasuruan namun juga sampai Kabupaten Malang. Oleh karena itu, diperlukan perluasan tempat usaha.

Pia Mahen berlokasi di jalan arteri baru Porong yang merupakan relokasi jalan baru akibat bencana lumpur di Porong sejak tahun 2009. Berdasarkan wawancara dengan pemilik, usahanya berkembang pesat sejalan dengan semakin meningkatnya pengguna jalan arteri Porong. Namun, sejak beroperasinya jalan tol Surabaya-Gempol Seksi Relokasi Porong-Gempol sejak akhir 2018, omset penjualan Pia Mahen mulai menurun sejalan dengan menurunnya pengguna jalan arteri Porong.

Lokasi Pengabdian Kepada Masyarakat (PKM) ini berada di rumah produksi Pia Mahen, Jalan Warurejo RT 3 RW 1, Dusun Warurejo, Desa Kejapanan, Kecamatan Gempol, Kabupaten Pasuruan, Provinsi Jawa Timur. Rumah produksi ini berada dalam kampung yang biasa disebut dengan Kampung Pia. Secara visual, lokasi PKM tersaji pada Gambar 1.

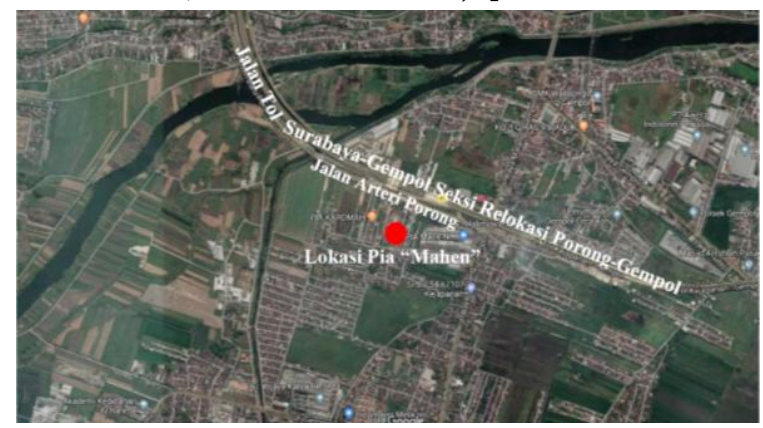

Gambar 1. Lokasi Tempat Usaha Pia Mahen (Google, 2019)

PKM ini sangat diperlukan untuk membantu pemilik showroom menaikkan omset melalui penjualan dan pelatihan. Desain workshop baru diharapkan bisa lebih efektif dan efisien sehingga proses produksi dan pelatihan bisa berjalan beriringan secara optimal untuk menarik kedatangan pembeli dan peserta pelatihan. Tujuan PKM ini adalah menyediakan desain workshop yang bisa dijadikan Bu Srinah sebagai panduan untuk merenovasi.

\section{Metode Pelaksanaan}

Agar bisa menghasilkan desain sesuai dengan kebutuhan pemilik usaha maka metode pelaksanaan PKM ini adalah dengan survei lokasi, wawancara, dan studi banding yang sesuai. Survei lokasi diperlukan untuk mengetahui ukuran dan kondisi eksisting. Wawancara ditujukan kepada pemilik usaha guna mengetahui rencana pengembangan usaha, alur aktivitas workshop dan pelatihan, serta menggali ide desain yang diinginkan. Gambar 2 menjelaskan metode pelaksanaan PKM ini.

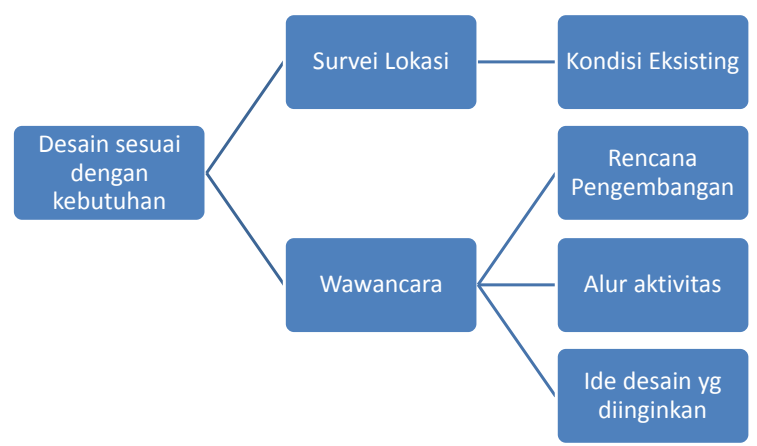

Gambar 2. Metode Pelaksanaan Pengabdian Kepada Masyarakat 


\section{Hasil dan Pembahasan}

\subsection{Survei Lokasi dan Wawancara}

Survei kondisi eksisting rumah produksi Pia Mahen telah dilakukan pada tanggal 12 Juli 2019 untuk mengukur dan mendengarkan penjelasan Bu Srinah tentang apa dan bagaimana masalah yang harus diselesaikan melalui desain ulang. Terdapat dua bagian pada rumah produksi, yaitu eksisting yang sudah digunakan sebagai rumah produksi dan showroom serta penambahan bagian samping baru untuk rencana perluasan pelatihan. Hasil survei lokasi tersaji pada Gambar 3.

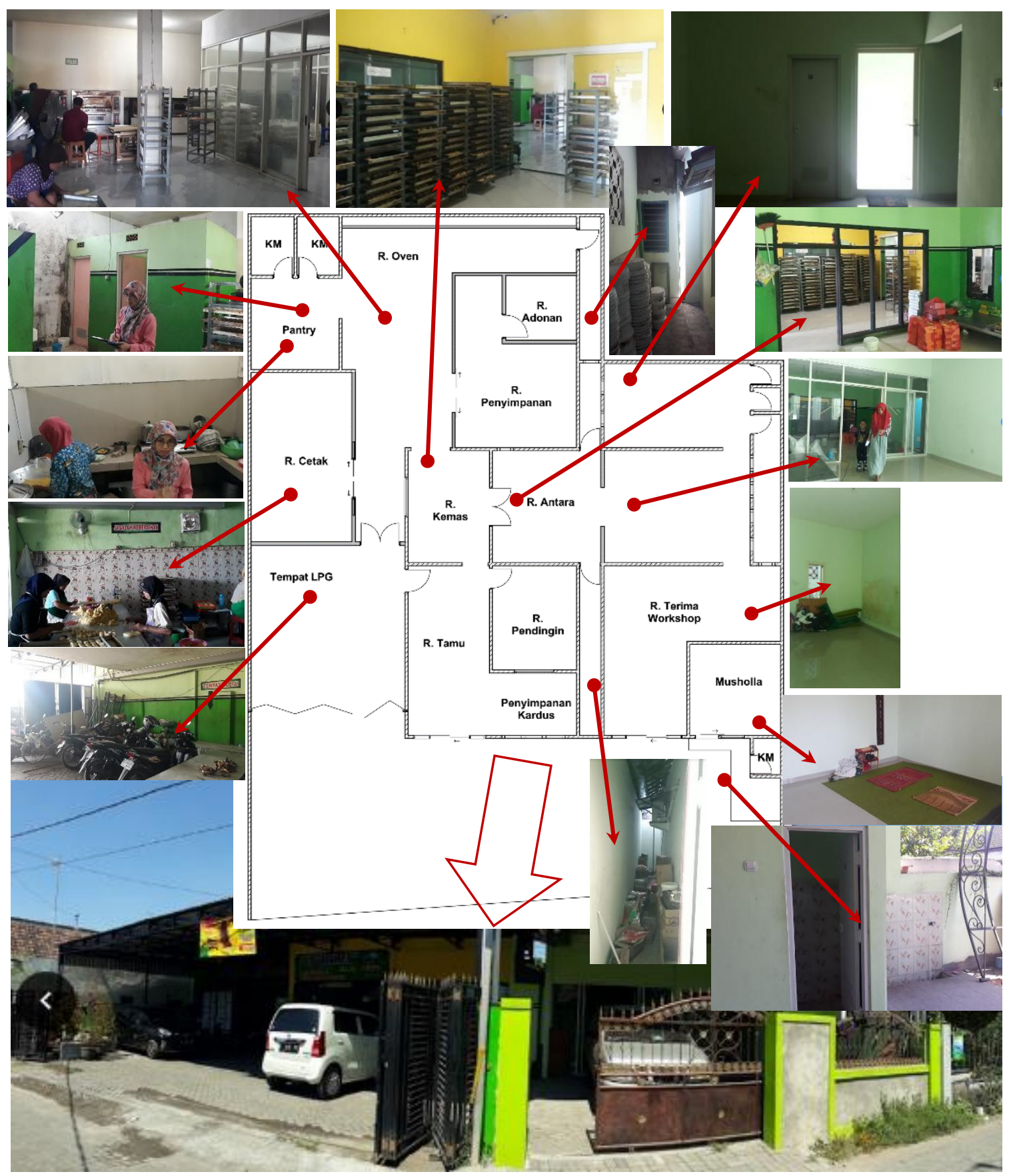

Gambar 3. Kondisi Eksisting Tempat Usaha Pia Mahen (Tim PKM, 2019) 


\subsection{Gambar Desain Ulang Workshop}

Hasil yang ingin dicapai dari desain ulang adalah efisiensi dan efektivitas dalam alur produksi dan pelatihan. Hal ini dilakukan melalui penambahan dan pengurangan sekat di beberapa ruang. Kemudian, beberapa fungsi ruang diubah agar sesuai dengan alur pembuatan produksi pia. Selain itu, beberapa exhaust fan diletakkan untuk mengalirkan udara agar ruangan lebih sejuk dan tidak pengap. Gambar 4 menunjukkan hasil desain ulang tempat usaha Pia Mahen.

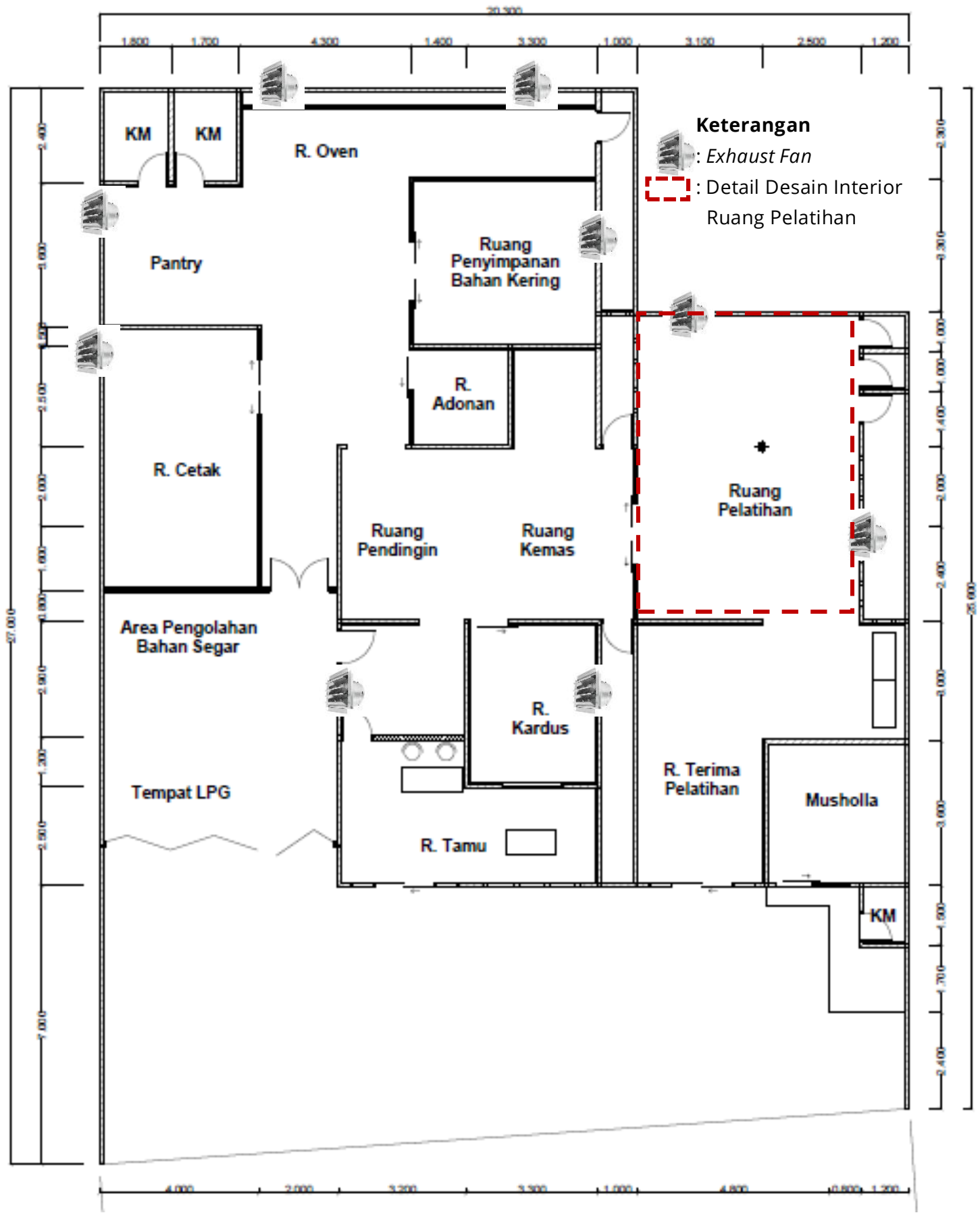

Gambar 4. Desain Ulang Layout Tempat Usaha Pia Mahen (Rolalisasi dkk., 2019) 
Area pelatihan ditempatkan pada perluasan dengan membuat desain interior agar lebih nyaman dan sesuai dengan kebutuhan. Ruangan depan dibiarkan kosong yang akan digunakan sebagai foyer penerima, sedangkan ruang di belakangnya untuk area pelatihan. Area pelatihan dibuat senyaman mungkin agar peserta pelatihan dan narasumber bisa berinteraksi dengan baik. Detail desain dapat dilihat pada Gambar 5-9.

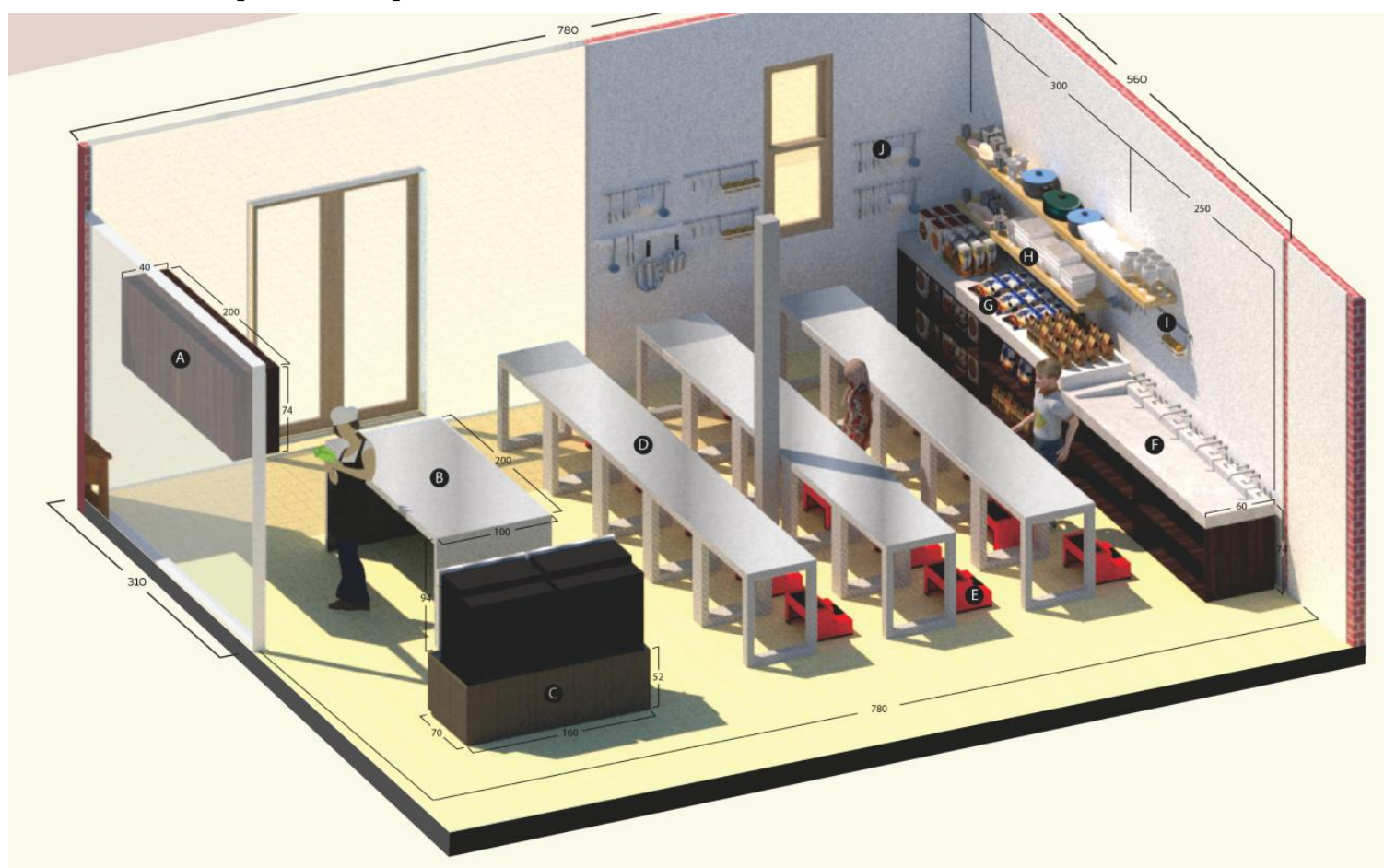

Gambar 5. Denah Tempat Usaha Pia Mahen (Rolalisasi dkk., 2019)

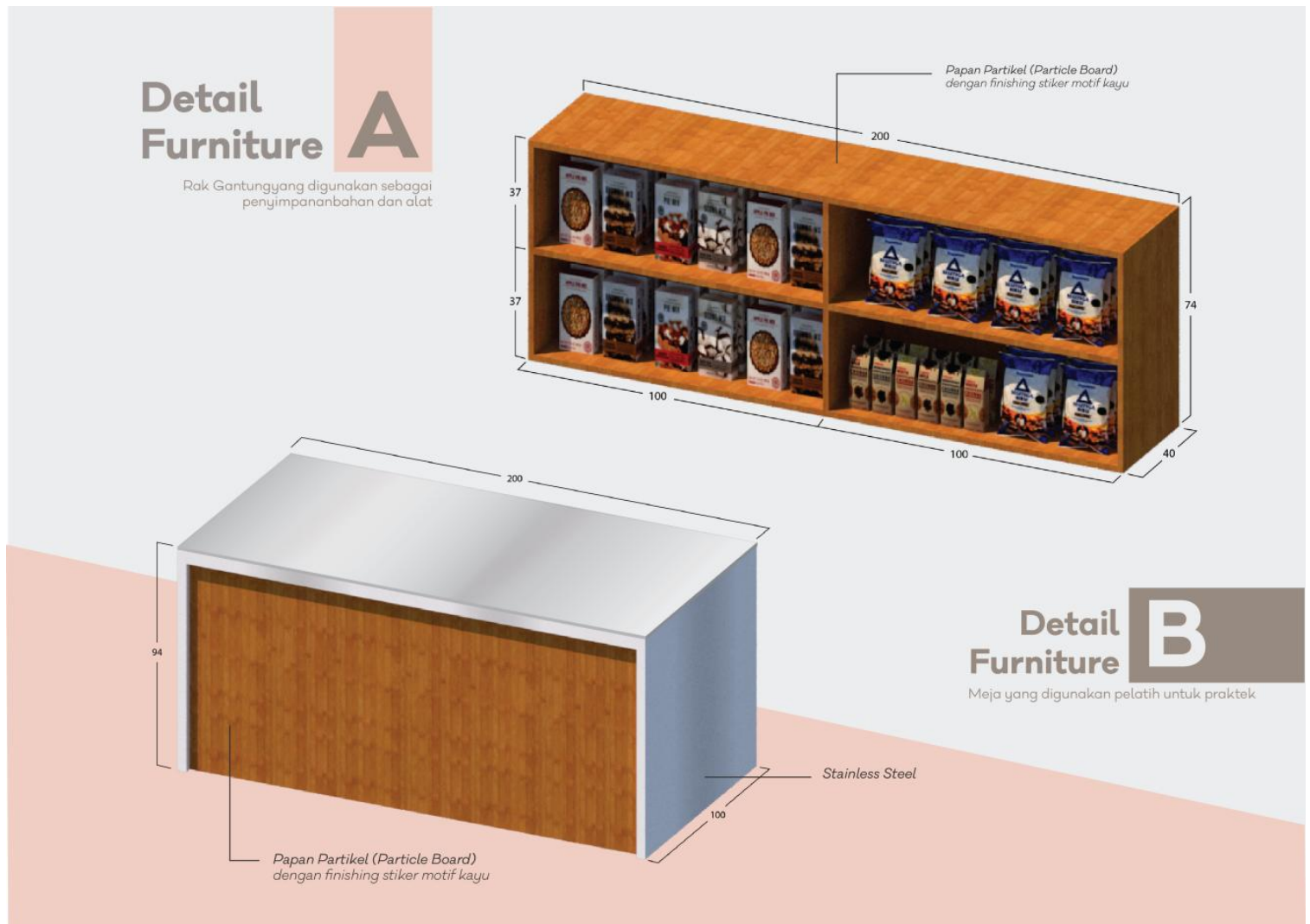

Gambar 6. Detail Furniture Rak Gantung dan Meja Praktek (Rolalisasi dkk., 2019) 


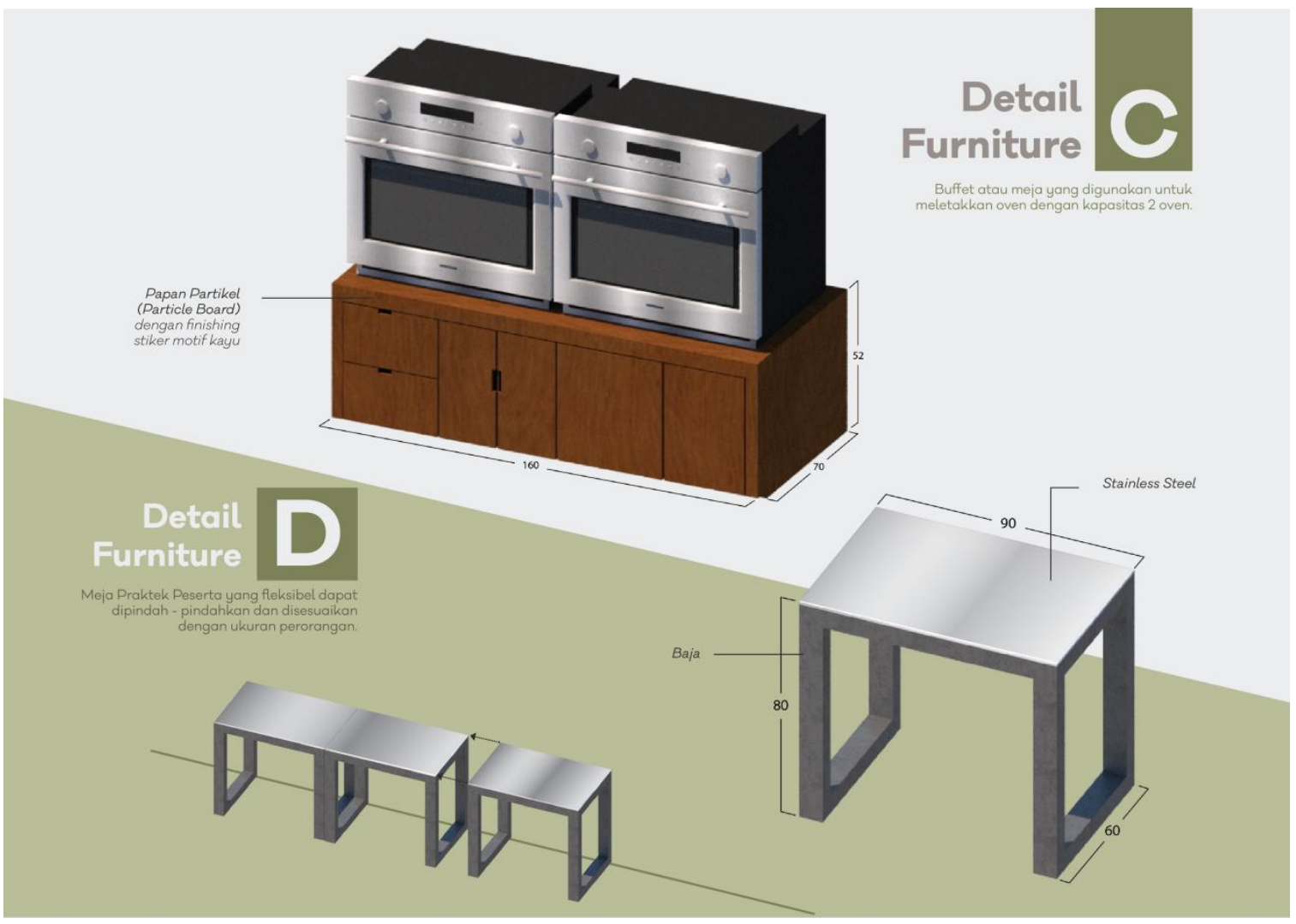

Gambar 7. Detail Meja Oven dan Meja Praktek untuk Peserta (Rolalisasi dkk., 2019)

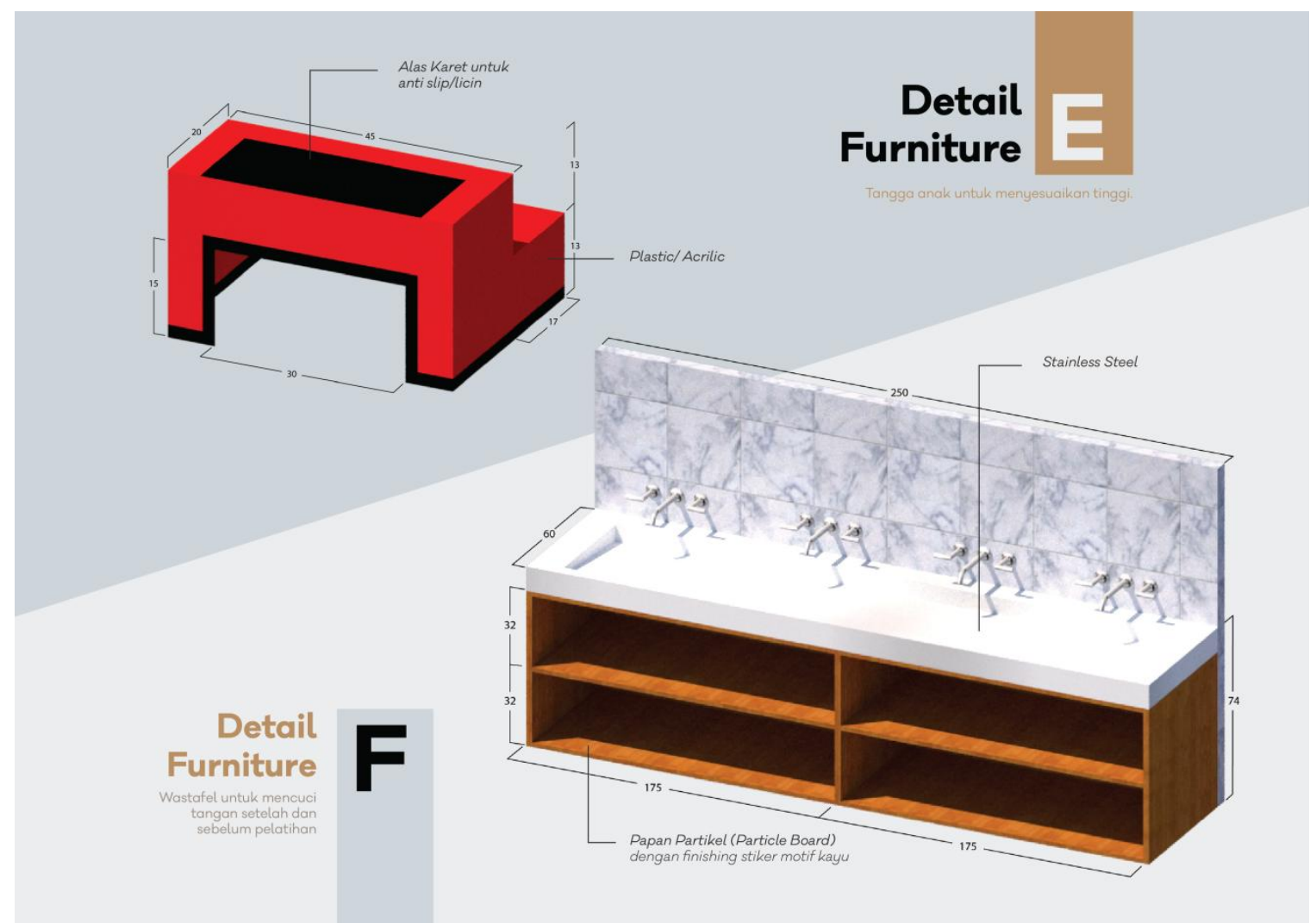

Gambar 8. Detail Pijakan untuk Anak-anak dan Wastafel (Rolalisasi dkk., 2019) 


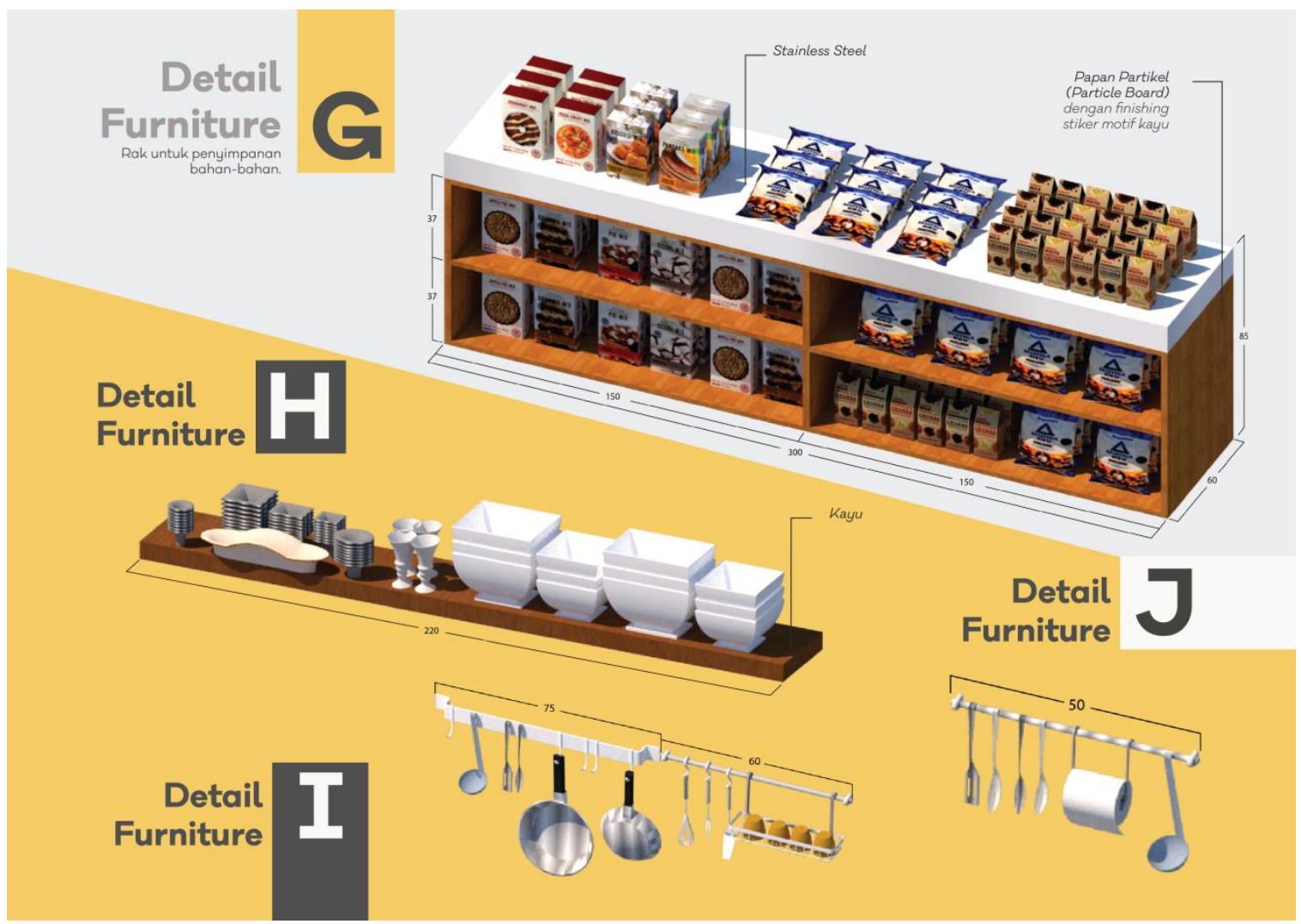

Gambar 9. Detail Rak Simpan dan Penggantung (Rolalisasi dkk., 2019)

Gambar desain dibuat sedetail dan sesederhana mungkin agar bisa menjadi panduan yang jelas bagi tukang. Untuk mempermudah, disediakan pula desain gambar secara tiga dimensi. Selain itu, material furnitur juga terdiri dari bahan-bahan yang mudah diperoleh di toko bahan bangunan setempat seperti stainless steel, papan partikel, dan lain-lain sehingga hasil renovasi diharapkan sesuai dengan gambar rancangan.

Selanjutnya, hasil desain dari PKM ini akan menjadi dasar pemilik usaha Pia Mahen untuk merenovasi tempat kerjanya agar kegiatan produksi dan pelatihan tidak membaur menjadi satu dan tidak saling mengganggu. Sebagai tindak lanjut, Universitas 17 Agustus 1945 (UNTAG) Surabaya diharapkan oleh pemilik untuk dapat melakukan PKM tahun 2020 melalui pendampingan renovasi tempat kerja.

\section{Kesimpulan}

Berdasarkan kegiatan PKM yang dilaksanakan di Pia Mahen, dapat disimpulkan bahwa pemasaran produk pia juga dapat dilakukan dengan memberikan pelatihan secara gratis agar bisa dikenal lebih luas lagi oleh masyarakat. Dengan demikian, Pia Mahen diharapkan dapat memberikan pengaruh positif bagi Kampung Pia di Pandaan secara umum.

\section{Ucapan Terima Kasih}

Terimakasih diucapkan kepada Universitas 17 Agustus 1945 (UNTAG) Surabaya atas pembiayaan kegiatan Pengabdian Kepada Masyarakat sumber dana perguruan tinggi tahun pelaksanaan 2019 dengan judul Branding Usaha Kecil melalui Redesain Tempat Usaha di Kec. Pandaan, Kab. Pasuruan melalui kontrak penugasan nomor 488.17/ST/003/LPPM/Abdimas/VII/2019. Terima kasih juga disampaikan kepada Bu Srinah yang bertindak sebagai pengusaha Pia Mahen. 


\section{Daftar Pustaka}

Google. (2019). Pia Mahen [Map]. Google Maps. https://goo.gl/maps/BBj444umvbod4ThL8

Mukhlis, J., \& Soetomo, S. (2017). Analisis Pengaruh Exit Toll Terhadap Tata Guna Lahan di Kabupaten Brebes. Jurnal Pembangunan Wilayah \& Kota, 13(3), 327-338. https://doi.org/10.14710/pwk.v13i3.17477

Rolalisasi, A., Kusumaningayu, I., Iffiyah, K., \& Hutama, S. F. (2019). Branding Usaha Kecil melalui Redesain Tempat Usaha di Kec. Pandaan, Kab. Pasuruan [Laporan PKM]. Universitas 17 Agustus 1945 Surabaya.

Sumaryoto, S. (2018). Dampak Keberadaan Jalan Tol Terhadap Kondisi Fisik, Sosial dan Ekonomi Lingkungannya. Journal of Rural and Development, 1(2), Article 2. https://jurnal.uns.ac.id /rural-and-development/article/view/23808

Tim PKM. (2019). Kondisi Eksisting Tempat Usaha Pia Mahen [Foto].

\section{Afiliasi:}

Andarita Rolalisasi ${ }^{(\star)}$, Intan Kusumaningayu, Khoudiy Iffiyah, Shinta Fiqi Hutama

Prodi Arsitektur, Fakultas Teknik, Universitas 17 Agustus 1945 Surabaya

Jl. Semolowaru 45, Surabaya

E-mail : rolalisasi@untag-sby.ac.id $\left.{ }^{(}\right)$,intankusuma@untag-sby.ac.id, iffiyahkhoudiy@gmail.com,shintafiqi@gmail.com 